\title{
Efficacy and Tolerability of Thermocoagulation Treatment of High-Grade Cervical Intraepithelial Neoplasia
}

\author{
Beatriz Maykot Kuerten 1*, Paulo Sérgio Viero Naud ${ }^{2}$, Francisco Jose Cidral-Filho ${ }^{3}$, \\ Armando José D’Acampora ${ }^{4}$
}

${ }^{1}$ Department of Obstetrics and Gynecology, Federal University of Santa Catarina, Florianópolis, Brazil

${ }^{2}$ Department of Obstetrics and Gynecology, Federal University of Rio Grande do Sul, Porto Alegre, Brazil

${ }^{3}$ Experimental Neuroscience Laboratory (LaNEx), Postgraduate Program in Health Sciences, University of Southern Santa

Catarina, Florianópolis, Brazil

${ }^{4}$ Department of Clinical Surgery, Federal University of Santa Catarina, Florianópolis, Brazil

Email: ^beakuerten@hotmail.com, „enfedrizzi@uol.com.br, pnaud@naud.com.br, cidral@gmail.com, dacampora@gmail.com

How to cite this paper: Kuerten, B.M., Naud, P.S.V., Cidral-Filho, F.J. and D'Acampora, A.J., (2021) Efficacy and Tolerability of Thermocoagulation Treatment of High-Grade Cervical Intraepithelial Neoplasia. Open Journal of Obstetrics and Gynecology, 11, 1691-1710.

https://doi.org/10.4236/ojog.2021.1112159

Received: October 20, 2021

Accepted: December 14, 2021

Published: December 17, 2021

Copyright $\odot 2021$ by author(s) and Scientific Research Publishing Inc. This work is licensed under the Creative Commons Attribution International License (CC BY 4.0).

http://creativecommons.org/licenses/by/4.0/

\begin{abstract}
Purpose: Cervical cancer is still one of the main causes of cancer and mortality in women, especially in low- and middle-income countries, although it is a completely preventable disease through the detection and treatment of pre-cancer lesions. We evaluated the efficacy and tolerability of thermocoagulation treatment of high-grade cervical intraepithelial neoplasia (CIN 2 and 3). Methods: We evaluated 115 women with high-grade cervical intraepithelial neoplasia, 54 with CIN 2 and 61 with CIN 3, confirmed by biopsy and without previous treatment, from January 2016 to December 2018, undergoing thermocoagulation treatment at the Lower Genital Tract Pathology and Colposcopy Service of the Hospital de Clinicas de Porto Alegre, Porto Alegre, Brazil. Results: The mean age was 33.11 years $(\mathrm{SD}=9.83)$ for CIN 2 and 35.28 years $(\mathrm{SD}=7.97)$ for CIN 3 patients. Treatment efficacy was $90.8 \%$ in CIN 2 and 94.9\% in CIN 3 cases. Pain was the main symptom reported at the time of treatment, occurring more frequently in the CIN 3 group (49.1\% versus $27.8 \%$ in the CIN 2 group). As the more important long-term complication, there were 3 cases of pelvic inflammatory disease in CIN 2 (5.6\%) and 3 in CIN 3 group (5.0\%). The percentage of residual lesion was very low in both groups, 5 in CIN 2 group (9.2\%) and 2 in CIN 3 group (3.4\%). Conclusion: Thermocoagulation is an effective method for the treatment of cervical pre-cancer lesions (CIN 2 and CIN 3), with a low risk of adverse events and complications.
\end{abstract}




\section{Keywords}

Cervical Intraepithelial Neoplasia, Thermocoagulation, Efficacy Results, Ablation Procedures, Cancer Prevention

\section{Introduction}

Cervical cancer occurs mainly in less developed countries (85\% of cases), being the fourth most common type of cancer among women worldwide. It is still the second most common cause of death and cancer in the female population in low- and middle-income countries [1]. It is responsible for about 311,000 deaths per year worldwide [2]. Mortality varies across different regions of the world, with rates ranging from less than 2 per 100,000 women in West Asia to 27.6/100,000 in East Africa [3].

This type of cancer is a completely preventable disease through the detection and treatment of pre-invasive lesions, cervical intraepithelial neoplasia (CIN) [4]. However, it is still a great challenge to carry out an organized screening and adequate treatment of all premalignant lesions diagnosed in the world [5].

There are several therapeutic options that can be used, depending on variables such as the possibility of access to the proposed treatment, histological degree of the lesion and its extension, professional experience, degree of cervical involvement, concomitant with other pathologies or pregnancy, age of the patient and reproductive desire. The latter should be considered in young women, since unfavorable obstetric outcomes are observed in some women after some types of treatments [6] [7].

In this context, there is a need to implement treatments that do not require super-specialized labor, as it would be of little use to offer treatments considered of technical excellence, where there are neither physical nor human resources to carry them out [8]. Simple treatments that can be implemented in regions with difficult access and easy follow-up after treatment would be preferable [9]. In the 1980 s and 1990s, the use of ablative (destructive) treatment methods changed the belief that surgical procedures and histological specimens are always needed for cases of high-grade squamous intraepithelial lesions (HSIL). So much so that nowadays the World Health Organization (WHO) recommends these treatments in places with low income [10].

Destructive or excisional treatment must be individualized for each case. In both approaches, when performed properly, the success rate is around 90\% [11] [12] [13]. Ablative treatment can be thermocoagulation, cryotherapy, electrocautery (thermal cautery) and chemical cauterization. The most used excisional methods are excision of the transformation zone and conization, which can be performed with a scalpel (cold knife conization), laser, electric procedures or high-frequency surgery [14]. The disadvantage of destructive methods is the absence of a histological sample for a definitive diagnosis. When there is doubt 
about the possibility of a (micro) invasion, the treatment must necessarily be excisional [7]. The risk of progression from a cervical lesion to cancer increases according to its severity, going from $<1 \%$ for CIN 1 to $5 \%$ for CIN 2 [15].

The most discussed ablative treatment in recent years is thermocoagulation, also known as cold coagulation or thermoablation [16]. The method uses a simple and inexpensive device and is easy to apply, with little discomfort for the woman and with high efficiency in resolving the lesion, and is currently recommended by the WHO, mainly for low-income and middle-income countries [17].

Thermocoagulation has been used all over the world, but more frequently in the United Kingdom (UK) from the 1980s [18] [19] [20]. It is indicated for any non-pregnant woman with $\mathrm{CIN} 2 / 3$, when the entire lesion is visible, the squamous-columnar junction is also fully visible, affecting up to $75 \%$ of the cervix and without extension to the endocervical canal [21] [22]. The procedure is quick, between 20 - 60 seconds per application and reaches a depth of $4-7 \mathrm{~mm}$ [23]. Temperature conduction in muscle tissue is relatively poor, therefore anesthesia is not necessary for most patients and complications and adverse effects are usually infrequent [24].

Several studies conducted recently have demonstrated the good results of thermocoagulation in the treatment of HSIL, with little need for re-treatment [25]. Efficacies range from $77 \%$ - 92\% for CIN 2 and $85 \%$ for CIN3 with infrequent side effects [26] [27].

The aim of this study was to evaluate the efficacy and tolerability of the ablative method of thermocoagulation with the Semm device in the treatment of women with high-grade squamous intraepithelial lesion (CIN 2/3) confirmed by biopsy, followed up for 24 months.

\section{Methods}

This study protocol was reviewed and approved by the Research Ethics Committee of the Hospital de Clinicas de Porto Alegre (IRB00000921-Project 100126). All study participants signed the Informed Consent Form.

\subsection{Study Design and Participants}

The sample evaluated consisted of 115 women aged between 25 and 59, with a histological diagnosis of CIN2 and 3, referred to Lower Genital Tract Pathology and Colposcopy Service of the Hospital de Clinicas de Porto Alegre, Porto Alegre, Brazil. Of these 115 women, 54 had CIN 2 and 61 CIN 3. Biopsy was considered the gold standard in diagnostic criteria and was repeated at the time the participants entered the study. We included in the study (inclusion criteria) all healthy women aged 25 - 59 years, with an intact uterus and no history of debilitating physical or mental illness, who required histologically proven treatment for HSIL (CIN 2 and CIN 3). All women who had at least one of the following criteria were excluded from the study (exclusion criteria): presence of infection 
or vaginal bleeding, cervical lesions with involvement of the endocervical canal, women who had undergone previous treatments, pregnant women and HIV positive women. Colposcopy was performed in all women and described according to the 2011 International Federation for Cervical Pathology and Colposcopy (IFCPC) nomenclature [11].

\subsection{Procedures}

All women underwent thermocoagulation treatment under colposcopic vision with the Semm'sthermocoagulator device (WISAP ${ }^{\circledR}$ brand by Medical Technology, Sauerlach, Germany). The temperature was calibrated at $100^{\circ} \mathrm{C}$ and the heated probe was placed over the transformation zone with CIN 2 or CIN 3 for 45 - 60 seconds. Two or more applications (a maximum of 5 in total) were performed according to the size of the lesion. Participants were observed for one hour after treatment to assess any adverse events after the procedure.

Instructions about post-treatment care and symptoms that could occur, such as cramping, clear or serosanguineous watery discharge, or a little blood for up to four weeks after treatment were given to all patients. Women were advised not to undergo vaginal showers and were advised to immediately notify the research team if they developed fever $\left(>37.8^{\circ} \mathrm{C}\right)$ or bleeding for more than 2 days, severe abdominal pain or purulent discharge.

\subsection{Outcomes}

All study participants were followed up and re-evaluated at 6, 12 and 24 months after the procedure. At 12 and 24 months post-treatment, patients underwent cytopathological examination and colposcopy to assess relapse or recurrence of HSIL or even the progression of the disease. A new thermocoagulation treatment was performed if the biopsy revealed the presence of a CIN 2/3. Possible complications of the procedure, such as fibrosis, cervical canal stenosis or infection, were also evaluated.

\subsection{Statistical Analysis}

To calculate the sample size, the online calculator available at http://www.praticaclinica.com.br/anexos/ccolaborativa-calculo-amostral/ccolab orativa-calculo-amostral.php was used. A sampling error of $5 \%$ was considered, with a confidence interval of $95 \%$, from a population consisting of 200 women/year attended at the Lower Genital Tract and Colposcopy Service of the Hospital de Clinicas de Porto Alegre. The success percentage was estimated according to the meta-analysis by Dolman et al. [12], with $95 \%$ as the maximum percentage. Thus, the calculated sample was 54 women. The initial sample of this study was 128 women, of which 13 (11.1\%) were excluded due to failure followup, leaving a final sample for analysis of 115 women, 54 cases of CIN 2 and 61 cases of CIN 3.

To describe the qualitative variables, absolute and relative frequencies were 
used, while to describe the quantitative variables, mean and standard deviation were used. The analyses were structured by separating the variables related to the CIN 2 and CIN 3 groups. To measure the accuracy of the colposcopy and cytopathology diagnosis, the biopsy result was used as another standard. To describe the success rate of the tests, exact $95 \%$ confidence intervals were constructed for binomial distributions. Also, to compare the accuracy of diagnosis between CIN 2 and CIN 3, Fisher's exact test was used. To associate the variables before treatment with the outcome 24 months after treatment, Fisher's exact test was used for qualitative variables and the Kruskal-Wallis test for quantitative variables. In order to assess the factors that influence the presence of lesion 24 months after treatment, logisticregression models and the Stepwise method were used to select variables. Variables that presented a p-value lower than 0.25 were selected for the multivariate analysis, and the Backward method was then applied, with a significant level of $5 \%$ was adopted. To verify if the adjusted model was adequate, some measures of goodness of fit were calculated, namely: Pseudo R2, Hosmer-Lemeshow test and accuracy parameters (AUC, Sensitivity and Specificity). The software used in the analyses was $\mathrm{R}$ (version 3.5.0).

\section{Results}

All women referred to the Lower Genital Tract Pathology and Colposcopy Service of the Hospital de Clinicasde Porto Alegre with a CIN 2/3 were submitted to an assessment of socio-demographic characteristics and a new analysis with colposcopy, cytology and biopsy and were divided in separate groups, those with CIN 2 and those with CIN 3.

\subsection{Analysis of CIN 2 Group before Treatment}

Regarding the group with CIN 2, the mean age of women was 33.1 years (standard deviation of 9.8 years), $35.2 \%$ were married, $55.6 \%$ had an education level of five to ten years and $64.8 \%$ had an income of one to three minimum wages. Most women (74.1\%) received only one application of thermocoagulation with the SEMM device and most were asymptomatic during the procedure (51.9\%). When any symptom was present, pain was the most frequent symptom (27.8\%), and its intensity was not categorized (Table 1).

\subsection{Analysis of CIN 2 Group after Treatment}

After treatment, cytology showed a negative result for most women at all visits, with $83.3 \%$ at 6 -month follow-up, $79.6 \%$ at 12 -month follow-up, and $85.1 \%$ at 24-month follow-up. Residual lesion on biopsy was observed in only five women at 12 months (9.3\%), all CIN 1 and also in five women at the 24-month assessment (9.2\%), with three CIN 1 (5.5\%) and two with CIN 2/3 (3.7\%). As a long-term complication, in the evaluation six months after treatment, $31.9 \%$ referred to have experienced some type of pain, pelvic or during sexual intercourse. At the 12-month evaluation, three cases of pelvic inflammatory disease 
Table 1. Descriptive analysis of CIN 2 group variables before treatment.

\begin{tabular}{|c|c|c|c|c|}
\hline & & & $\mathbf{N}$ & $\%$ \\
\hline & Age & (Average/DP) & (33.1 years) & ( \pm 9.8 years) \\
\hline \multirow{12}{*}{$\begin{array}{c}\text { Sociodemographic } \\
\text { Variables }\end{array}$} & \multirow{5}{*}{ Marital Status } & Single & 17 & 31.5 \\
\hline & & Married & 19 & 35.2 \\
\hline & & Stable Union & 12 & 22.1 \\
\hline & & Divorced & 3 & 5.6 \\
\hline & & Widow & 3 & 5.6 \\
\hline & \multirow{3}{*}{ Years of Schooling } & $1-5$ years & 7 & 13.0 \\
\hline & & 5 to 10 years & 30 & 55.6 \\
\hline & & $>$ that 10 years & 17 & 31.4 \\
\hline & \multirow[t]{4}{*}{$\begin{array}{c}\text { Income } \\
\text { (in minimum wages) }\end{array}$} & $<1$ & 15 & 27.8 \\
\hline & & 1 to 3 & 35 & 64.8 \\
\hline & & 3.5 to 5 & 2 & 3.7 \\
\hline & & $>5$ & 2 & 3.7 \\
\hline \multirow{3}{*}{ Colposcopy } & \multirow{3}{*}{$\begin{array}{l}\text { Colposcopy } \\
\text { Findings }\end{array}$} & Negative & 1 & 1.9 \\
\hline & & Probable LSIL & 2 & 3.7 \\
\hline & & Probable HSIL & 51 & 94.4 \\
\hline \multirow{4}{*}{ Cytopathology } & \multirow[t]{4}{*}{ Results } & Negative & 4 & 7.4 \\
\hline & & ASC-US & 13 & 24.1 \\
\hline & & LSIL & 14 & 25.9 \\
\hline & & HSIL & 23 & 42.6 \\
\hline \multirow[t]{4}{*}{ Biopsy } & Result & CIN 2 & 54 & 100 \\
\hline & & 1 & 40 & 74.1 \\
\hline & $\begin{array}{l}\text { Number of } \\
\text { applications }\end{array}$ & 2 & 13 & 24.1 \\
\hline & & 3 & 1 & 1.8 \\
\hline \multirow[t]{4}{*}{ Thermocoagulation } & \multirow{4}{*}{$\begin{array}{c}\text { Side effects during } \\
\text { Treatment }\end{array}$} & \multirow{2}{*}{ Asymptomatic Pain } & 28 & 51.9 \\
\hline & & & 15 & 27.8 \\
\hline & & Sensation of vaginal heat & 6 & 11.1 \\
\hline & & Bleeding & 5 & 9.2 \\
\hline
\end{tabular}

Abbreviations: ASC-US: atypia of squamous cells of undetermined meaning; LSIL: Low-grade squamous intraepithelial lesion; HSIL: High-grade squamous intraepithelial lesion.

(PID) (5.0\%) were diagnosed ('Table 2).

\subsection{Analysis of CIN 3 Group before Treatment}

In relation to the group with $\mathrm{CIN} 3$, the mean age of women was 35.2 years

(standard deviation of 7.9 years), $54.1 \%$ were married, $49.2 \%$ had an education 
Table 2. Descriptive analysis of CIN 2 group variables after treatment.

\begin{tabular}{|c|c|c|c|c|}
\hline Monitoring & Variables & Result & $\mathrm{N}$ & $\%$ \\
\hline \multirow{5}{*}{6 months } & \multirow{3}{*}{ Cytopathology } & Negative & 45 & 83.3 \\
\hline & & ASC-US & 8 & 14.8 \\
\hline & & LSIL & 1 & 1.9 \\
\hline & \multirow{2}{*}{ Complications } & Pain & 21 & 31.9 \\
\hline & & Purulent flow & 5 & 9.3 \\
\hline \multirow{13}{*}{12 Months } & \multirow[t]{4}{*}{ Cytopathology } & Negative & 43 & 79.6 \\
\hline & & ASC-US & 9 & 16.6 \\
\hline & & LSIL & 1 & 1.9 \\
\hline & & HSIL & 1 & 1.9 \\
\hline & \multirow[t]{2}{*}{ Colposcopy } & Negative & 48 & 88.9 \\
\hline & & Positive & 6 & 11.1 \\
\hline & \multirow{3}{*}{ Biopsy } & Not performed & 45 & 83.3 \\
\hline & & Negative & 4 & 7.4 \\
\hline & & CIN 1 & 5 & 9.3 \\
\hline & \multirow[t]{2}{*}{ General Status } & No injury & 49 & 90.7 \\
\hline & & Residual Injury & 5 & 9.3 \\
\hline & \multirow[t]{2}{*}{ Long-term Complications } & None & 51 & 94.4 \\
\hline & & Pelvic Inflammatory Disease & 3 & 5.6 \\
\hline \multirow{8}{*}{24 Months } & \multirow{4}{*}{ Cytopathology } & Negative & 46 & 85.1 \\
\hline & & ASC-US & 3 & 5.6 \\
\hline & & LSIL & 3 & 5.6 \\
\hline & & HSIL & 2 & 3.7 \\
\hline & \multirow{4}{*}{ Biopsy } & Negative & 2 & 3.7 \\
\hline & & CIN 1 & 3 & 5.5 \\
\hline & & CIN 2/3 & 2 & 3.7 \\
\hline & & Not Performed & 47 & 87.1 \\
\hline
\end{tabular}

Abbreviations: ASC-US: atypia of squamous cells of undetermined meaning; LSIL: Low-grade squamous, intraepithelial lesion; HSIL: High-grade squamous intraepithelial lesion; CIN: Cervical intraepithelial neoplasia.

level of five to ten years and $52.5 \%$ had an income of one to three minimum wages. Most women needed only one thermocoagulation $(44.3 \%)$ or two $(41 \%)$. Pain was the most frequent symptom associated with the procedure, having been observed in $49.1 \%$, and its intensity was not categorized (Table 3 ).

\subsection{Analysis of CIN 3 Group after Treatment}

After treatment, cytology indicated a negative result for most women at all visits, with $73.8 \%$ at 6 -month follow-up, $70.5 \%$ at 12 -month follow-up, and $93.2 \%$ at 24-month follow-up. Residual lesion on biopsy was observed in only five women 
Table 3. Descriptive analysis of CIN 3 group variables before treatment.

\begin{tabular}{|c|c|c|c|c|}
\hline & Variables & & $\mathrm{N}$ & $\%$ \\
\hline & Age & (Average/SD) & (35.2 years) & ( \pm 7.9 years) \\
\hline \multirow{12}{*}{$\begin{array}{c}\text { Sociodemographic } \\
\text { Variables }\end{array}$} & \multirow{5}{*}{ Marital Status } & Single & 14 & 23.0 \\
\hline & & Married & 33 & 54.1 \\
\hline & & Stable Union & 11 & 18.0 \\
\hline & & Divorced & 2 & 3.3 \\
\hline & & Widow & 1 & 1.6 \\
\hline & \multirow{3}{*}{ Years of Schooling } & 1 to 5 years & 12 & 19.7 \\
\hline & & 5 to 10 years & 30 & 49.2 \\
\hline & & $>$ than 10 years & 19 & 31.1 \\
\hline & \multirow{4}{*}{$\begin{array}{c}\text { Income } \\
\text { (in minimum wages) }\end{array}$} & $<1$ & 24 & 39.3 \\
\hline & & 1 to 3 & 32 & 52.5 \\
\hline & & 3 to 5 & 4 & 6.6 \\
\hline & & $>5$ & 1 & 1.6 \\
\hline \multirow[t]{2}{*}{ Colposcopy } & \multirow[t]{2}{*}{ Colposcopy findings } & Probable LSIL & 4 & 6.5 \\
\hline & & Probable HSIL & 57 & 93.5 \\
\hline \multirow{4}{*}{ Cytopathology } & \multirow[t]{4}{*}{ Results } & Negative & 3 & 4.9 \\
\hline & & ASC-US & 10 & 16.4 \\
\hline & & LSIL & 8 & 13.1 \\
\hline & & HSIL & 40 & 65.6 \\
\hline Biopsy & Results & CIN 3 & 61 & 100 \\
\hline \multirow{8}{*}{ Thermocoagulation } & \multirow{5}{*}{$\begin{array}{l}\text { Number of } \\
\text { Applications }\end{array}$} & 1 & 27 & 44.3 \\
\hline & & 2 & 25 & 41.0 \\
\hline & & 3 & 8 & 13.1 \\
\hline & & 5 & 1 & 1.6 \\
\hline & & Asymptomatic & 19 & 31.1 \\
\hline & \multirow{3}{*}{$\begin{array}{l}\text { Side effects During } \\
\text { Treatment }\end{array}$} & Pain & 30 & 49.1 \\
\hline & & Sensation of vaginal heat & 11 & 18.1 \\
\hline & & Bleeding & 1 & 1.7 \\
\hline
\end{tabular}

Abbreviations: ASC-US: atypia of squamous cells of undetermined meaning; LSIL: Low-grade squamous intraepithelial lesion; HSIL: High-grade squamous intraepithelial lesion; CIN: Cervical intraepithelial neoplasia.

in 12 months (8.2\%), three cases of CIN 1 (4.9\%) and two cases of CIN $2 / 3$ (3.3\%). In the 24-month evaluation, only two women had the lesion, being considered as a recurrence, with one case of CIN 1 (1.7\%) and one case of CIN 2/3 (1.7\%). As a long-term complication, in the evaluation six months after treat- 
ment, $19.7 \%$ referred to have some type of pain, pelvic or during sexual intercourse. At the 12-month evaluation, three cases of pelvic inflammatory disease (5.0\%) were diagnosed (Table 4 ).

\subsection{Outcome 24 Months after the Treatment}

In an analysis of association between the variables before treatment and the

Table 4. Descriptive analysis of CIN 3 group variables after treatment.

\begin{tabular}{|c|c|c|c|c|}
\hline Monitoring & Variables & Results & $\mathrm{N}$ & $\%$ \\
\hline \multirow{5}{*}{6 Months } & \multirow{3}{*}{ Cytopathology } & Negative & 45 & 73.8 \\
\hline & & ASC-US & 13 & 21.3 \\
\hline & & LSIL & 3 & 4.9 \\
\hline & \multirow{2}{*}{ Complications } & Pain & 12 & 19.7 \\
\hline & & Purulent Flow & 8 & 13.1 \\
\hline \multirow{15}{*}{12 Months } & \multirow{4}{*}{ Cytopathology } & Negative & 43 & 70.5 \\
\hline & & ASC-US & 13 & 21.3 \\
\hline & & LSIL & 3 & 4.9 \\
\hline & & HSIL & 2 & 3.3 \\
\hline & \multirow{2}{*}{ Colposcopy } & Negative & 56 & 91.8 \\
\hline & & Positive & 5 & 8.2 \\
\hline & \multirow{4}{*}{ Biopsy } & Not Performed & 54 & 88.5 \\
\hline & & Negative & 2 & 3.3 \\
\hline & & CIN 1 & 3 & 4.9 \\
\hline & & CIN $2 / 3$ & 2 & 3.3 \\
\hline & \multirow{2}{*}{ General Status } & No Injury & 56 & 91.8 \\
\hline & & Residual Injury & 5 & 8.2 \\
\hline & \multirow{3}{*}{ Long-term complications } & Absence & 52 & 85.2 \\
\hline & & Pain & 6 & 9.8 \\
\hline & & Pelvic Inflammatory Disease & 3 & 5.0 \\
\hline \multirow{8}{*}{24 Months [8] } & \multirow{4}{*}{ Cytopathology } & Negative & 55 & 93.2 \\
\hline & & ASC-US & 2 & 3.4 \\
\hline & & CIN 1 & 1 & 1.7 \\
\hline & & CIN $2 / 3$ & 1 & 1.7 \\
\hline & \multirow{4}{*}{ Biopsy } & Absence of Injury & 2 & 3.4 \\
\hline & & CIN 1 & 1 & 1.7 \\
\hline & & CIN $2 / 3$ & 1 & 1.7 \\
\hline & & Not Performed & 55 & 93.2 \\
\hline
\end{tabular}

Abbreviations: ASC-US: atypia of squamous cells of undetermined meaning; LSIL: Low-grade squamous intraepithelial lesion; HSIL: High-grade squamous intraepithelial lesion; CIN: Cervical intraepithelial neoplasia. ${ }^{*}$ Two participants were excluded for having been hysterectomized. 
Table 5. Analysis of the association between the variables before treatment and outcome 24 months after thermocoagulation in CIN 2 Group, evaluated by cytopathology.

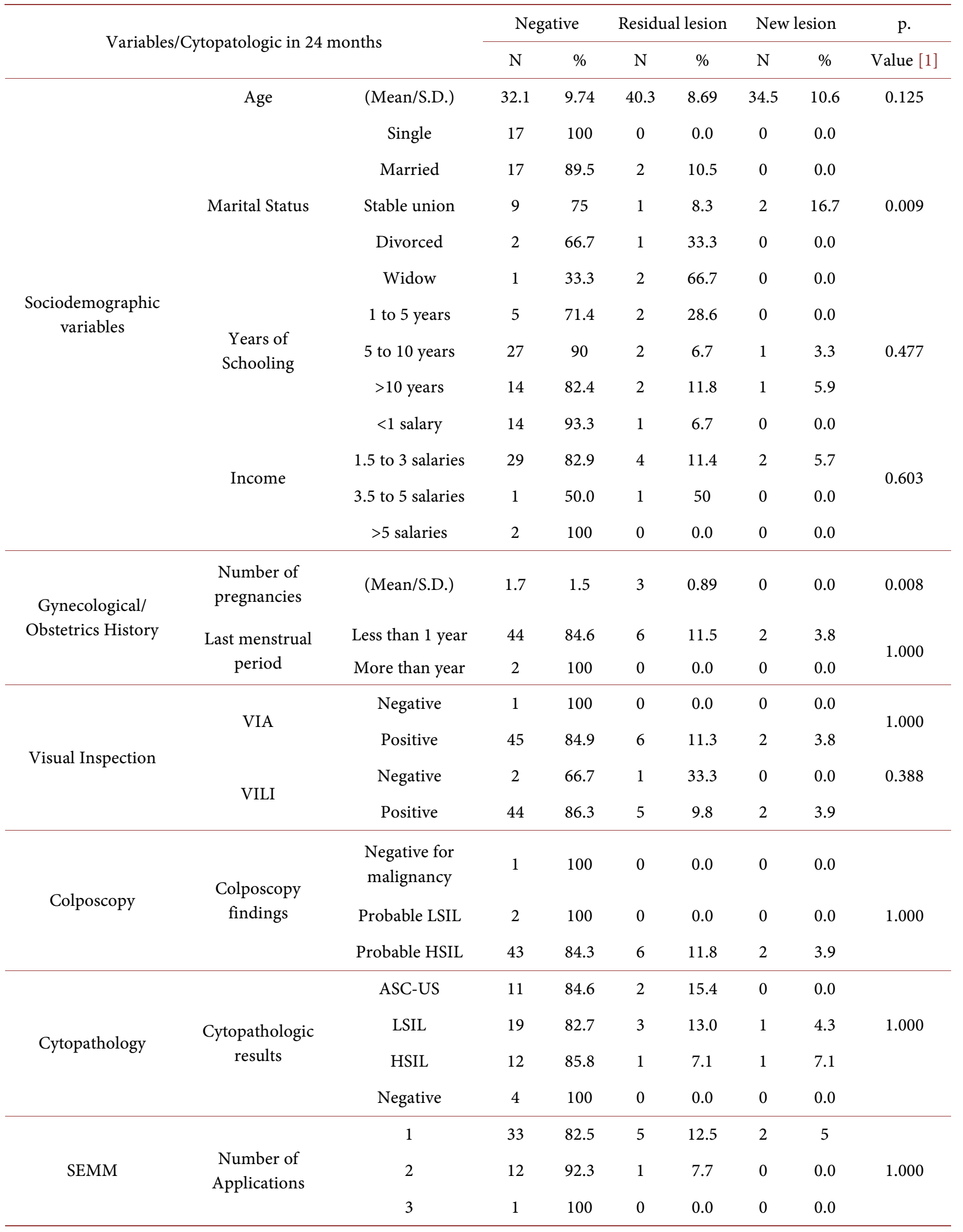




$\begin{array}{ccccccccc} & \text { No symptoms } & 25 & 89.3 & 3 & 10.7 & 0 & 0.0 & \\ & \text { Pain/Cramping } & 12 & 80.0 & 2 & 13.3 & 1 & 6.7 & \\ \begin{array}{c}\text { Side effects during } \\ \text { the procedure }\end{array} & \text { Bleeding/heat } & 3 & 100 & 0 & 0.0 & 0 & 0.0 & 0.382 \\ & \text { Bleeding } & 4 & 80 & 1 & 20.0 & 0 & 0.0 & \\ & \text { Heat sensation } & 2 & 66.7 & 0 & 0.0 & 1 & 33.3\end{array}$

Abbreviations: ASC-US: atypia of squamous cells of undetermined meaning; LSIL: Low-grade squamous intraepithelial lesion; HSIL: High-grade squamous intraepithelial lesion; VIA: Visual inspection after application of acetic acid 5\%; VILI: Visual inspection after application of iodopovidone.

Table 6. Analysis of the association between the variables before treatment and outcome 24 months after thermocoagulation in CIN 3 Group, evaluated by cytopathology.

\begin{tabular}{|c|c|c|c|c|c|c|c|c|c|}
\hline \multicolumn{3}{|c|}{ Variables/Cytopatologic in 24 months } & \multicolumn{2}{|c|}{ Negative } & \multicolumn{2}{|c|}{$\begin{array}{l}\text { Residual } \\
\text { lesion }\end{array}$} & \multicolumn{2}{|c|}{ New lesion } & \multirow{2}{*}{$\begin{array}{c}\text { p. } \\
\text { Value [1] }\end{array}$} \\
\hline & & & $\mathrm{N}$ & $\%$ & $\mathrm{~N}$ & $\%$ & $\mathrm{~N}$ & $\%$ & \\
\hline \multirow{13}{*}{$\begin{array}{c}\text { Sociodemographic } \\
\text { variables }\end{array}$} & Age & (Mean/S.D.) & 34.8 & 7.5 & 40.3 & 11.3 & 33.1 & 6.2 & 0.437 \\
\hline & \multirow{5}{*}{ Marital Status } & Single & 11 & 78.6 & 1 & 7.1 & 2 & 14.3 & \multirow{5}{*}{0.178} \\
\hline & & Married & 28 & 84.8 & 3 & 9.1 & 2 & 6.1 & \\
\hline & & Stable Union & 8 & 72.7 & 1 & 9.1 & 2 & 18.2 & \\
\hline & & Divorced & 1 & 50.0 & 1 & 50.0 & 0 & 0.0 & \\
\hline & & Widow & 0 & 0.0 & 1 & 100.0 & 0 & 0.0 & \\
\hline & \multirow{3}{*}{$\begin{array}{l}\text { Years of } \\
\text { Schooling }\end{array}$} & 1 to 5 years & 10 & 81.8 & 2 & 18.2 & 0 & 0.0 & \multirow{3}{*}{0.342} \\
\hline & & 5 to 10 years & 25 & 83.4 & 1 & 3.3 & 4 & 13.3 & \\
\hline & & $>10$ years & 13 & 68.4 & 4 & 21.1 & 2 & 10.5 & \\
\hline & \multirow{4}{*}{ Income } & $<1$ salary & 17 & 70.8 & 5 & 20.8 & 2 & 8.3 & \multirow{4}{*}{0.466} \\
\hline & & 1.5 to 3 salaries & 27 & 84.4 & 2 & 6.3 & 3 & 9.4 & \\
\hline & & 3.5 to 5 salaries & 3 & 75.0 & 0 & 0.0 & 1 & 25.0 & \\
\hline & & $>5$ salaries & 1 & 100.0 & 0 & 0.0 & 0 & 0.0 & \\
\hline \multirow{3}{*}{$\begin{array}{l}\text { Gynecological/ } \\
\text { Obsterics History }\end{array}$} & $\begin{array}{l}\text { Number of } \\
\text { pregnancies }\end{array}$ & (Mean/S.D.) & 2.2 & 1.5 & 2 & 1.8 & 1.7 & 1.2 & 0.515 \\
\hline & \multirow{2}{*}{$\begin{array}{l}\text { Last menstrual } \\
\text { period }\end{array}$} & Less than 1 year & 43 & 78.2 & 6 & 10.9 & 6 & 10.9 & \multirow[b]{2}{*}{0.779} \\
\hline & & $\begin{array}{c}\text { More than a } \\
\text { year }\end{array}$ & 5 & 83.3 & 1 & 16.7 & 0 & 0.0 & \\
\hline \multirow{4}{*}{ Visual Inspection } & \multirow{2}{*}{ VIA } & Negative & 4 & 80.0 & 1 & 20.0 & 0 & 0.0 & \multirow{2}{*}{0.712} \\
\hline & & Positive & 44 & 78.6 & 6 & 10.7 & 6 & 10.7 & \\
\hline & \multirow{2}{*}{ VILI } & Negative & 3 & 100.0 & 0 & 0.0 & 0 & 0.0 & \multirow{2}{*}{1.000} \\
\hline & & Positive & 45 & 77.6 & 7 & 12.1 & 6 & 10.3 & \\
\hline \multirow[t]{2}{*}{ Colposcopy } & \multirow[t]{2}{*}{$\begin{array}{l}\text { Findings of } \\
\text { colposcopy }\end{array}$} & Probable LSIL & 4 & 100.0 & 0 & 0.0 & 0 & 0.0 & \multirow[t]{2}{*}{0.350} \\
\hline & & Probable HSIL & 44 & 77.2 & 7 & 12.6 & 6 & 10.2 & \\
\hline
\end{tabular}




\section{Continued}

\begin{tabular}{|c|c|c|c|c|c|c|c|c|c|}
\hline \multirow{4}{*}{ Cytopathology } & \multirow{4}{*}{$\begin{array}{l}\text { Cytopathologic } \\
\text { results }\end{array}$} & ASC-US & 7 & 70.0 & 2 & 20.0 & 1 & 10.0 & \multirow{4}{*}{0.930} \\
\hline & & LSIL & 7 & 87.5 & 0 & 0.0 & 1 & 12.5 & \\
\hline & & HSIL & 31 & 77.5 & 5 & 12.5 & 4 & 10.0 & \\
\hline & & Negative & 3 & 100.0 & 0 & 0.0 & 0 & 0.0 & \\
\hline \multirow{8}{*}{ SEMM } & \multirow{3}{*}{$\begin{array}{l}\text { Number of } \\
\text { Applications }\end{array}$} & 1 & 25 & 88.9 & 2 & 7.4 & 1 & 3.7 & \multirow{3}{*}{0.496} \\
\hline & & 2 & 17 & 68.0 & 4 & 16.0 & 4 & 16.0 & \\
\hline & & 3 & 6 & 75.0 & 1 & 12.5 & 1 & 12.5 & \\
\hline & \multirow{5}{*}{$\begin{array}{l}\text { Side effects } \\
\text { during the } \\
\text { procedure }\end{array}$} & No symptoms & 16 & 83.3 & 2 & 11.1 & 1 & 5.6 & \multirow{5}{*}{0.689} \\
\hline & & Pain/Cramping & 23 & 76.7 & 3 & 10.0 & 4 & 13.3 & \\
\hline & & $\begin{array}{c}\text { Bleeding and } \\
\text { Heat }\end{array}$ & 1 & 100 & 0 & 0.0 & 0 & 0.0 & \\
\hline & & Bleeding & 6 & 85.7 & 1 & 14.3 & 0 & 0.0 & \\
\hline & & Heat sensation & 2 & 50.0 & 1 & 25.0 & 1 & 25.0 & \\
\hline
\end{tabular}

Abbreviations: ASC-US: atypia of squamous cells of undetermined meaning; LSIL: Low-grade squamous intraepithelial lesion; HSIL: High-grade squamous intraepithelial lesion; VIA: Visual inspection after application of acetic acid 5\%; VILI: Visual inspection after application of iodopovidone.

outcome 24 months after the treatment of CIN 2, assessed through cytopathological examination, women with a higher number of pregnancies were more likely to have a residual lesion, compared to women with a smaller number of children ( $\mathrm{p}=0.008)$ (Table 5). This same analysis in the CIN 3 group did not show a significant association in any variable analyzed in relation to the outcome at 24 months after treatment (Table 6).

To analyze the factors associated with the presence of lesion 24 months after treatment, logistic regression models were adjusted, and the selection of variables was performed using the Stepwise Method. In the multivariate analysis of factors associated with the presence of lesion 24 months after CIN 2 treatment, we observed that the older age was the greater chance of lesion 24 months after treatment, however this result was not statistically significant. The other variables did not show a significant value in the multivariate analysis and were not selected for the univariate analysis. Therefore, there was no significance of the possible factors associated with the presence of residual lesion 24 months after the treatment of CIN 2 (Table S1). When we evaluated the CIN 3 group, in relation to factors associated with the presence of residual lesion 24 months after treatment, we observed that the chance was lower for women with more than one minimum wage and that the chance was higher for women with more than ten years of education and who had had more than one application of thermocoagulation, however these results were not significant (Table S2).

\section{Discussion}

Thermocoagulation has been shown to be a good option for the treatment of 
pre-cancerous lesions of the cervix, including high-grade ones, in several studies [8] [9] [12] [13] [14] [16] [17] [18] [19] [20] [23]-[30]. We observed a high efficacy in the treatment of CIN 2/3 lesions with thermocoagulation, with cytology normalizing in six months of $83 \%$ for CIN 2 and $74 \%$ for CIN 3 . When we evaluate the 24-month period, the percentages rise to $85 \%$ for CIN 2 and $93 \%$ for CIN 3. In a meta-analysis carried out by Dolman et al., with 4569 women treated with thermocoagulation, the result was similar, with an $84.2 \%$ resolution for CIN 2/3, also based on cytology, colposcopy and biopsy, when necessary [12]. In the meta-analysis by Randall et al., which included more less-developed countries, this percentage of efficacy for curing CIN 2/3 was higher, 93.8\% [29]. These results are similar to those observed with excisional treatments (cold conization, with $90 \%$ - 94\% success rate, high frequency surgery, in $91 \%$ - 98\%, and laser conization with $93 \%-96 \%$ ) [31], considered as treatment first choice for these cases of high-grade lesions, but requiring specialized training [8] [31]. For places with less infrastructure for this type of treatment, ablative treatments (thermocoagulation, cryotherapy or electrocautery) are options that should be evaluated, especially in young women without children, as they have fewer complications that can interfere with fertility, as occurs with excisional methods [8].

The device used in this study may bring advantages to the thermocoagulation procedure, as it is lightweight and portable, and runs on electricity or battery. Cryocauterization requires a heavy cylinder and gas replacement, not always available in many low-resource locations. Electrocauterization usually requires anesthesia, as it is very uncomfortable [8] [12] [31]. The WHO classifies thermocoagulation as 1.A evidence for the treatment of CIN 2/3 lesions [30].

We had no recurrence of cytology with high-grade lesion after six months of CIN 2/3 treatment. Papoutsis et al. observed recurrence within six months in $2.8 \%$ of women with CIN $2 / 3$ treated with thermocoagulation. In the 12 -month follow-up, our recurrence was $3.3 \%$ and for this same author a little less, $1.2 \%$ [28]. In any event, this recurrence is much smaller than those reported for excisional treatments, which range from 3.5\% - 25\% [32]. However, this difference may be a consequence of the variability of the study methodology, with different definitions of recurrence, inclusion and exclusion criteria from the study, lesion extension and evaluation with cytology or histopathology or both [33].

The number of thermocoagulation applications depends on the size of the lesion. Generally, more severe lesions tend to be more extensive than less severe ones, which is why the vast majority of CIN 2 were treated with just one application (74\%), while CIN 3 required more applications, with two in $41 \%$ of the cases. The depth of the lesion is also proportional to its severity. The depth of thermocoagulation can reach $2.5-4 \mathrm{~mm}$ after treatment at $100^{\circ} \mathrm{C}$ for 30 seconds and always exceeds $4 \mathrm{~mm}$ if $120^{\circ} \mathrm{C}$ is used for the same time. This is sufficient for the treatment of $\mathrm{CIN}$, since studies show that the average involvement of crypts in their depth is $1.24 \mathrm{~mm}$ [18]. 
The most frequent symptom associated with thermocoagulation was pain, especially when it was necessary to perform more than one session of the procedure, as observed in women with CIN 3, where $49 \%$ reported this discomfort, while in women with CIN 2, where the majority did only one session, pain was reported in only $28 \%$ of the cases. Most studies refer to pain as the main symptom associated with the method, ranging from 3.5\% (severe pain) to $25 \%$ (mild pain) [12]. Nessa et al., evaluating women treated in Brazil and India had a higher percentage of pain during the procedure, 52\% [13].

Cervical stenosis or its incompetence is the most frequent long-term effect of traditional methods of treating high-grade cervical lesions, especially with excisional methods [12]. With thermocoagulation, we did not observe any cases of stenosis, which is important for the maintenance of fertility in these women, most of whom are in menacme. Isthmus-cervical incompetence occurs in excisional methods, depending on the extent of removal of the lesion. The 2017 Cochrane Review showed an increased risk of preterm birth associated with excisional treatments $(\mathrm{RR}=1.87 ; 95 \% \mathrm{CI}$ : $1.64-2.12)$ when compared to ablative methods ( $\mathrm{RR}=1.35$; 95\% CI: 1.20 - 1.52) [34].

Our study had some limitations. Despite the small sample size, the 24-month follow-up was sufficient to robustly assess the effectiveness of thermocoagulation in the treatment of CIN 2/3. Another limitation was the non-inclusion of HPV-DNA tests as a criterion for healing the treated lesions. Currently, this test has been considered essential for the post-treatment follow-up of high-grade cervical lesions [19].

In conclusion, thermocoagulation with a Semm device showed excellent efficacy in the treatment of $2 / 3 \mathrm{CIN}$, with most women reporting little or no discomfort with the procedure. The method showed good tolerability, with high adherence to treatment follow-up in an observation period of up to 24 months, a time considered to be at risk for the onset of lesion recurrences.

\section{Acknowledgements}

We would like to thank professor Edison Natal Fedrizzi for reviewing this study.

\section{Author Contributions}

All authors contributed to the development, drafting, writing and editing of this manuscript.

\section{Approval}

This study was approved by the ethics committee of the hospital de clinicas de Porto Alegre, Federal University of Rio Grande do Sul (IRB00000921-Project 10-0126).

\section{Conflicts of Interest}

The authors declare no conflicts of interest. 


\section{References}

[1] Instituto Nacional do Câncer (INCA) (2020) Atlas da mortalidade por câncer no Brasil. https://mortalidade.inca.gov.br/MortalidadeWeb/

[2] Instituto Nacional do Câncer (INCA) (2021) Estatísticas de câncer. https://www.inca.gov.br/numeros-de-cancer

[3] Ferlay, J., Soerjomataram, I., Ervik, M., Dikshit, R., Eser, S., Mathers, C., et al. (Eds.) (2013) GLOBOCAN 2012: Cancer Incidence and Mortality Worldwide. IARC Cancerbase No. 11, International Agency for Research on Cancer (IARC), Lyon. http://globocan.iarc.fr

[4] Sellors, J.W. and Sankaranarayanan, R. (2004) Colposcopia e tratamento da neoplasia intra-epitelial cervical: Manual para principiantes. IARC Press, Whashington DC. https://screening.iarc.fr/doc/colpoptmanual.pdf

[5] Instituto Nacional do Câncer (INCA) (2021) Controle do câncer do colo do úteroConceito e magnitude. Instituto Nacional do Câncer-Ministério da Saúde, Brasília. https://www.inca.gov.br/controle-do-cancer-do-colo-do-utero/conceito-e-magnitud e\#: :text=O\%20c\%C3\%A2ncer\%20do\%20colo\%20do,\%C3\%B3rg\%C3\%A3os\%20co nt\%C3\%ADguos\%20ou\%20\%C3\%A0\%20dist\%C3\%A2ncia

[6] Cremer, M.L., Consuelo-Rodriguez, G., Cherniak, W. and Randall, T. (2018) Ablative Therapies for Cervical Intraepithelialneoplasia in Low-Resource Settings: Findingsand Key Questions. Journal of Global Oncology, 4, 1-10. https://doi.org/10.1200/JGO.18.00093

[7] Lopes, V.A.Z. and Ribeiro, J.M. (2019) Fatores limitadores e facilitadores para o controle do câncer de colo de útero: Uma revisão de literatura. Ciência \& Saúde Coletiva, 24, 3431-3442. https://doi.org/10.1590/1413-81232018249.32592017

[8] Castle, P.E., Murokora, D., Perez, C., Alvarez, M., Quek, S.C. and Campbell, C. (2017) Treatment of Cervical Intraepithelial Lesions. International Journal of $G y$ necology \& Obstetrics, 138, 20-25. https://doi.org/10.1002/ijgo.12191

[9] Allam, M., Paterson, A., Thomson, A., Ray, B., Rajagopalan, C. and Sarkar, G. (2005) Large Loop Excision and Cold Coagulation for Management of Cervical Intraepithelial Neoplasia. International Journal of Gynecology \& Obstetrics, 88, 38-43. https://doi.org/10.1016/j.ijgo.2004.09.019

[10] Organização Pan-Americana de Saúde Brasil (OPAS) and Organização Mundial da Saúde (OMS) (2016) Diretrizes da OMS para triagem e tratamento de lesões précancerosas para prevenção do câncer cervical.

https://www.paho.org/bra/index.php?option=com_content\&view=article\&id=5319: opas-oms-lanca-versao-em-portugues-de-guia-para-prevencao-e-controle-do-cance $\underline{\text { r-do-colo-do-utero\&Itemid }=839}$

[11] Baloglu, A., Uysal, D., Bakircioglu, I., Bicer, M. and Inci, A. (2010) Residual and Recurrent Disease Rates Following LEEP Treatment in High-Grade Cervical Intraepithelial Lesions. Archives of Gynecology and Obstetrics, 282, 69-73. https://doi.org/10.1007/s00404-009-1298-3

[12] Dolman, L., Sauvaget, C., Muwonge, R. and Sankaranarayanan, R. (2014) MetaAnalysis of the Efficacy of Cold Coagulation as a Treatment Method for Cervical intraepithelial Neoplasia: A Systematic Review. BJOG: An International Journal of Obstetrics \& Gynaecology, 121, 929-942. https://doi.org/10.1111/1471-0528.12655

[13] Nessa, A., Naud, P., Esmy, P., Joshi, S., Rema, P., Wesley, R., et al. (2017) Efficacy, Safety, and Acceptability of Thermal Coagulation to Treat Cervical Intraepithelial Neoplasia: Pooled Data from Bangladesh, Brazil and India. Clinical Obstetrics and 
Gynecology, 6, 58-64. https://doi.org/10.14740/jcgo464w

[14] Santesso, N., Mustafa, R., Schünemann, H., et al. (2016) World Health Organization Guidelines for Treatment of Cervical Intraepithelial Neoplasia 2-3 and Screen-andTreat Strategie to Prevent Cervical Cancer. International Journal of Gynecology \& Obstetrics, 132, 252-258. https://doi.org/10.1016/j.ijgo.2015.07.038

[15] Castle, P.E., Schiffmann, M., Wheeler, C.M. and Solomon, D. (2009) Evidence for Frequent Regression of Cervical Intraepithelial Neoplasia-Grade 2. Obstetrics \& Gynecology, 113, 18-25. https://doi.org/10.1097/AOG.0b013e31818f5008

[16] De Fouw, M., Oosting, R.M., Rutgrink, A., Dekkers, O.M., Peters, A.A.W. and Beltman, J.J. (2019) A Systematic Review and Meta-Analysis of Thermal Coagulation Compared with Cryotherapy to Treat Precancerous Cervical Lesions in Lowand Middle-Income Countries. International Journal of Gynecology \& Obstetrics, 147, 4-18. https://doi.org/10.1002/ijgo.12904

[17] World Health Organization (WHO) (2014) WHO Guidelines for Treatment of Cervical Intraepithelial Neoplasia 2-3 and Adenocarcinoma in Situ. World Health Organization, Geneva.

http://apps.who.int/iris/bitstream/handle/10665/104174/9789241506779_eng.pdf;jse ssionid $=$ CCF388F6C839D2A8370F372DC5A5207B? sequence $=1$

[18] Gordon, H.K. and Duncan, I.D. (1991) Effective Destruction of Cervical Intraepithelial Neoplasia (CIN) 3 at $100^{\circ} \mathrm{C}$ Using the Semm Cold Coagulator: 14 Years Experience. BJOG: An International Journal of Obstetrics \& Gynaecology, 98, 14-20. https://doi.org/10.1111/j.1471-0528.1991.tb10304.x

[19] Tadesse, W.G., Oni, A.A.A. and Hickey, K.P.W. (2019) Effectiveness of Cold Coagulation in Treating High-Grade Cervical Intraepithelial Neoplasia: The Human Papillomavirus Evidence of Cure. Journal of Obstetrics and Gynaecology, 39, 965-968. https://doi.org/10.1080/01443615.2019.1581737

[20] Parry-Smith, W., Underwood, M., De Bellis-Ayres, S., Bangs, L., Redman, C.W. and Panikkar, J. (2015) Success Rate of Cold Coagulation for the Treatment of Cervical Intraepithelial Neoplasia: A Retrospective Analysis of a Series of Cases. Journal of Lower Genital Tract Disease, 19, 17-21. https://doi.org/10.1097/LGT.0000000000000031

[21] Aref-Adib, M., Phan, T. and Ades, A. (2019) Preventing Adhesions in Laparoscopic Surgery: The Role of Anti-Adhesion Agents. The Obstetrician \& Gynaecologist, 21, 185-192. https://doi.org/10.1111/tog.12588

[22] Joshi, S., Sankaranarayanan, R., Muwonge, R., Kulkarni, V., Somanathan, T. and Divate, U. (2013) Screening of Cervical Neoplasia in HIV-Infected Women in India. AIDS, 27, 607-615. https://doi.org/10.1097/QAD.0b013e32835b1041

[23] Haddad, N.G., Hussein, I.Y., Blessing, K., Kerr-Wilson, R. and Smart, G.E. (1988) Tissue Destruction Following Cold Coagulation of the Cervix. Journal of Gynecologic Surgery, 4, 23-27. https://doi.org/10.1089/gyn.1988.4.23

[24] Viviano, M., Kenfack, B., Catarino, R., Tincho, E., Temogne, L., Benski, A.-C., et al. (2017) Feasibility of Thermocoagulation in a Screen-and-Treat Approach for the Treatment of Cervical Precancerous Lesions in Sub-Saharan Africa. BMC Women's Health, 17, Article No. 2. https://doi.org/10.1186/s12905-016-0355-x

[25] McCarthy, C.M., Ramphul, M., Madden, M. and Hickey, K. (2016) The Use and Success of Cold Coagulation for the Treatment of High Grade Squamous Cervical Intraepithelial Neoplasia: A Retrospective Review. European Journal of Obstetrics \& Gynecology and Reproductive Biology, 203, 225-228. 
https://doi.org/10.1016/j.ejogrb.2016.05.029

[26] Loobuyck, H.A., Duncan, I.D. (1993) Destruction of CIN 1 and 2 with the Semm cold Coagulator: 13 Years' Experience with a See-and-Treat Policy. BJOG: An International Journal of Obstetrics \& Gynaecology, 100, 465-468. https://doi.org/10.1111/j.1471-0528.1993.tb15273.x

[27] Helm, C.W. (2014) There Is Still Some Heat in the Cold Coagulator. Mini Commentary on "Meta-Analysis of the Efficacy of Cold Coagulation as a Treatment Method for Cervical Intraepithelial Neoplasia: A Systematic Review”. BJOG: An International Journal of Obstetrics \& Gynaecology, 121, 929-942. https://doi.org/10.1111/1471-0528.12655

[28] Papoutsis, D., Underwood, M., Parry-Smith, W. and Panikkar, J. (2017) Comparison of Cure Rates in Women Treated with Cold-Coagulation versus LLETZ Cervical Treatment for CIN2-3 on Pretreatment Cervical Punch Biopsies: A Retrospective Cohort Study. Archives of Gynecology and Obstetrics, 295, 979-986. https://doi.org/10.1007/s00404-017-4306-Z

[29] Randall, T.C., Sauvaget, C., Muwonge, R., Trimble, E.L. and Jeronimo, J. (2019) Worthy of Further Consideration: An Updated Meta-Analysis to Address the Feasibility, Acceptability, Safety and Efficacy of Thermal Ablation in the Treatment of Cervical Cancer Precursor Lesions. Preventive Medicine, 118, 81-91. https://doi.org/10.1016/j.ypmed.2018.10.006

[30] World Health Organization (WHO) (2020) WHO Guidelines for the Use of Thermal Ablation for Cervical Pre-Cancer Lesions. World Health Organization, Geneva. https://www.ncbi.nlm.nih.gov/books/NBK549182/

[31] Martin-Hirsch, P.P., Paraskevaidis, E., Bryant, A., Dickinson, H.O. and Keep, S.L. (2010) Surgery for Cervical Intraepithelial Neoplasia. Cochrane Database of Systematic Reviews, No. 6, Article No. CD001318. https://doi.org/10.1002/14651858.CD001318.pub2

[32] Kocken, M., Helmerhorst, T.J., Berkhof, J., Louwers, J.A., Nobbenhuis, M.A.E., Bais, A.G., et al. (2011) Risk of Recurrent High-Grade Cervical Intraepithelial Neoplasia after Successful Treatment: A Long-Term Multi-Cohort Study. Lancet Oncology, 12, 441-450. https://doi.org/10.1016/S1470-2045(11)70078-X

[33] Ang, C., Mukhopadhyay, A., Burnley, C., Faulkner, K., Cross, P., Martin-Hirsch, P., et al. (2011) Histological Recurrence and Depth of Loop Treatment of the Cervix in Women of Reproductive Age: Incomplete Excision versus Adverse Pregnancy Outcome. BJOG: An International Journal of Obstetrics \& Gynaecology, 118, 685-692. https://doi.org/10.1111/j.1471-0528.2011.02929.x

[34] Kyrgiou, M., Athanasiou, A., Kalliala, I.E.J., Paraskevaidi, M., Mitra, A., Martin-Hirsch, P.P.L., et al. (2017) Obstetric Outcomes after Conservative Treatment for Cervical Intraepithelial Lesions and Early Invasive Disease. Cochrane Database of Systematic Reviews, No. 11, Article No. CD012847. https://doi.org/10.1002/14651858.CD012847 


\section{Abbreviations}

ASC-US: atypia of squamous cells of undetermined meaning;

CIN: cervical intraepithelial neoplasia;

CIN 1: cervical intraepithelial neoplasia grade 1 (mild);

CIN 2: cervical intraepithelial neoplasia grade 2 (moderate);

CIN 3: cervical intraepithelial neoplasia grade 3 (severe);

HIV: human immunodeficiency virus;

HPV: human papillomavirus;

HSIL: high-grade squamous intraepithelial lesions;

IFCPC: International Federation for Cervical Pathology and Colposcopy;

LSIL: low-grade squamous intraepithelial lesions;

PID: pelvic inflammatory disease;

VIA: visual inspection after application of acetic acid 5\%;

VILI: visual inspection after application of iodopovidone;

WHO: World Health Organization. 


\section{Supplementary Tables}

Table S1. Multivariate analysis of factors associated with the presence of residual or new lesion 24 months after treatment in the CIN 2 Group.

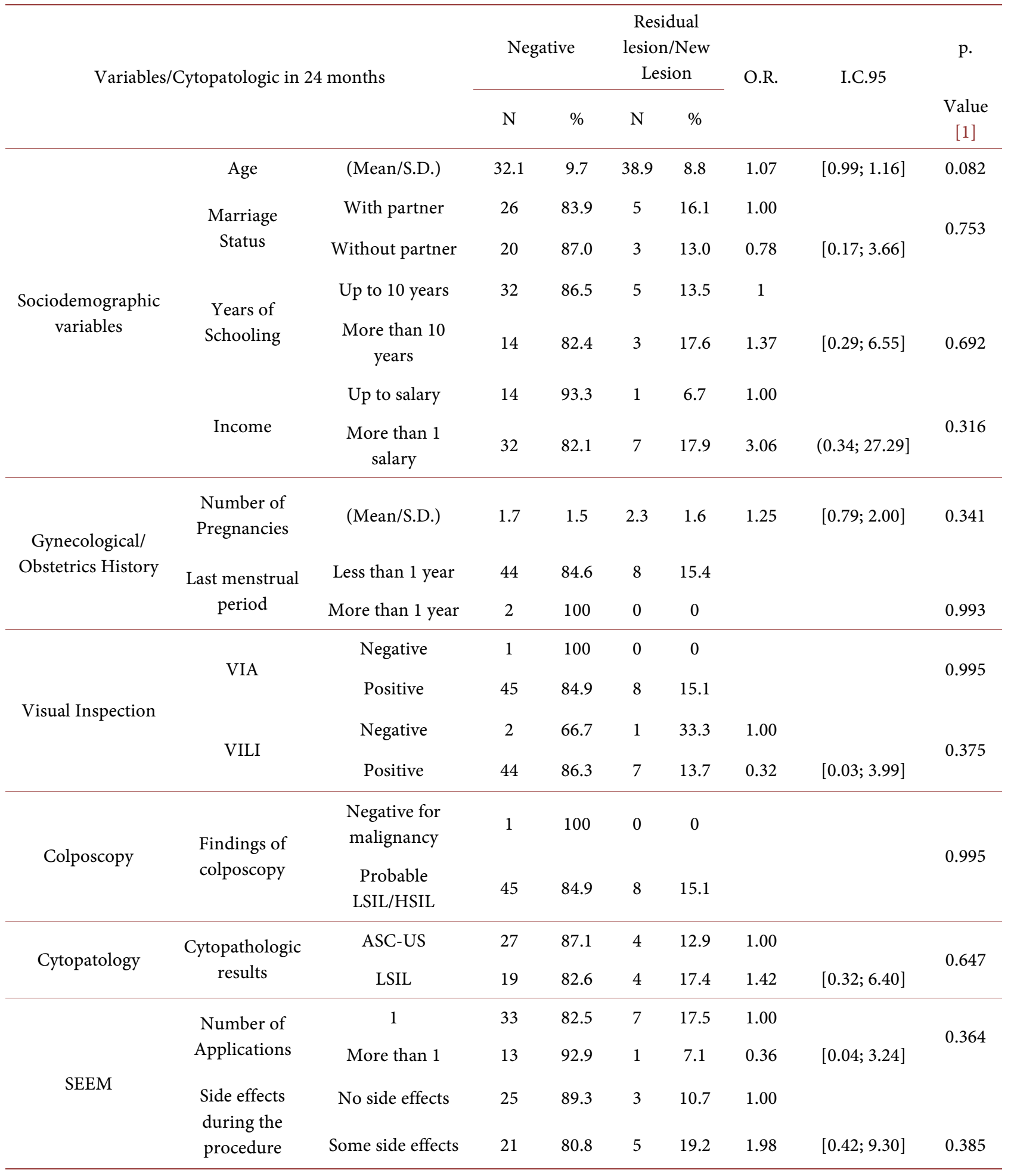

Abbreviations: ASC-US: atypia of squamous cells of undetermined meaning; LSIL: Low-grade squamous intraepithelial lesion; HSIL: High-grade squamous intraepithelial lesion; VIA: Visual inspection after application of acetic acid 5\%; VILI: Visual inspection after application of iodopovidone. 
Table S2. Multivariate analysis of factors associated with the presence of residual or new lesion 24 months after treatment in CIN 3 Group.

\begin{tabular}{|c|c|c|c|c|c|c|c|c|c|}
\hline \multicolumn{3}{|c|}{ Variables/Cytopatologic in 24 months } & \multicolumn{2}{|c|}{ Negative } & \multicolumn{2}{|c|}{$\begin{array}{c}\text { Residual } \\
\text { lesion/New } \\
\text { Lesion }\end{array}$} & \multirow[t]{2}{*}{ O.R. } & \multirow[t]{2}{*}{ I.C.95 } & \multirow{2}{*}{$\begin{array}{c}\text { p. } \\
\text { Value [1] }\end{array}$} \\
\hline & & & $\mathrm{N}$ & $\%$ & $\mathrm{~N}$ & $\%$ & & & \\
\hline \multirow{7}{*}{$\begin{array}{c}\text { Sociodemographic } \\
\text { variables }\end{array}$} & Age & (Mean/S.D.) & 34.8 & 7.5 & 37.1 & 9.7 & 1.03 & {$[0.96 ; 1.11]$} & 0.361 \\
\hline & Marriage & With partner & 36 & 81.8 & 8 & 18.2 & 1 & & \multirow{2}{*}{0.341} \\
\hline & Status & Without partner & 12 & 70.6 & 5 & 29.4 & 1.88 & {$[0.51 ; 6.84]$} & \\
\hline & Years of & Up to 10 years & 35 & 83.3 & 7 & 16.7 & 1.00 & & \\
\hline & Schooling & More than 10 years & 13 & 68.4 & 6 & 31.6 & 2.31 & {$[0.65 ; 8.16]$} & 0.194 \\
\hline & \multirow{2}{*}{ Income } & Up to salary & 17 & 70.8 & 7 & 29.2 & 1.00 & & \multirow{2}{*}{0.233} \\
\hline & & More than 1 salary & 31 & 83.8 & 6 & 16.2 & 0.47 & {$[0.14 ; 1.53]$} & \\
\hline \multirow{3}{*}{$\begin{array}{l}\text { Gynecological/ } \\
\text { Obstetrics History }\end{array}$} & $\begin{array}{l}\text { Number of } \\
\text { Pregnancies }\end{array}$ & (Mean/S.D.) & 2.3 & 1.5 & 1.8 & 1.5 & 0.79 & {$[0.48 ; 1.25]$} & 0.339 \\
\hline & \multirow{2}{*}{$\begin{array}{l}\text { Last menstrual } \\
\text { period }\end{array}$} & Less than 1 year & 43 & 78.2 & 12 & 21.8 & 1.00 & & \\
\hline & & More than 1 year & 5 & 83.3 & 1 & 16.7 & 0.72 & {$[0.08 ; 6.73]$} & 0.771 \\
\hline \multirow{4}{*}{$\begin{array}{c}\text { Visual } \\
\text { Inspection }\end{array}$} & \multirow{2}{*}{ VIA } & Negative & 4 & 80 & 1 & 20 & 1 & \multirow{4}{*}[0.11;10.69]{} & \\
\hline & & Positive & 44 & 78.6 & 12 & 21.4 & 1.09 & & 0.940 \\
\hline & \multirow{2}{*}{ VILI } & Negative & 3 & 100 & 0 & 0 & & & \\
\hline & & Positive & 45 & 77.6 & 13 & 22.4 & & & 0.994 \\
\hline \multirow{2}{*}{ Colposcopy } & \multirow{2}{*}{$\begin{array}{l}\text { Colposcopy } \\
\text { Findings }\end{array}$} & $\begin{array}{l}\text { Negative for } \\
\text { malignancy }\end{array}$ & 4 & 100 & 0 & 0 & & & \\
\hline & & $\begin{array}{l}\text { Probable } \\
\text { LSIL/HSIL }\end{array}$ & 44 & 77.2 & 13 & 22.8 & & & 0.993 \\
\hline \multirow{2}{*}{ Cytopatology } & \multirow{2}{*}{$\begin{array}{l}\text { Cytopathologic } \\
\text { results }\end{array}$} & ASCUS & 17 & 81 & 4 & 19 & 1 & & \multirow{2}{*}{0.755} \\
\hline & & LSIL & 31 & 77.5 & 9 & 22.5 & 1.23 & {$[0.33 ; 4.61]$} & \\
\hline \multirow{4}{*}{ SEMM } & \multirow{2}{*}{$\begin{array}{l}\text { Number of } \\
\text { Applications }\end{array}$} & 1 & 24 & 88.9 & 3 & 11.1 & 1 & & \multirow{2}{*}{0.094} \\
\hline & & More than 1 & 24 & 70.6 & 10 & 29.4 & 3.33 & {$[0.81 ; 13.64]$} & \\
\hline & Side effects & No side effects & 16 & 83.3 & 3 & 16.7 & 1 & & \\
\hline & procedure & Some side effects & 32 & 76.2 & 10 & 23.8 & 1.56 & {$[0.37 ; 6.52]$} & 0.540 \\
\hline
\end{tabular}

Abbreviations: ASC-US: atypia of squamous cells of undetermined meaning; LSIL: Low-grade squamous intraepithelial lesion; HSIL: High-grade squamous intraepithelial lesion; VIA: Visual inspection after application of acetic acid 5\%; VILI: Visual inspection after application of iodopovidone. 